\title{
How Important Are Dispositional Factors as Determinants of Job Satisfaction? Implications for Job Design and Other Personnel Programs
}

\author{
Barry Gerhart \\ Center for Advanced Human Resource Studies, New York State School of Industrial \\ and Labor Relations, Cornell University
}

\begin{abstract}
According to recent research, stable dispositional factors may result in considerable consistency in attitudes such as job satisfaction across time and situations. If true, this finding may have important implications. For example, Staw and Ross (1985) argued that "many situational changes such as job redesign . . . may not affect individuals as intended." Such personnel programs "may be prone to failure because they must contend with attitudinal consistency" (p. 478). The present article has two purposes. First, methodological and conceptual problems with the Staw and Ross assessment of the impact of situational and dispositional factors on job satisfaction are discussed. Second, given Staw and Ross's focus on job redesign, this article examines the impact on job satisfaction of changes in two very different measures of job complexity. Findings indicate that changes in situational factors such as job complexity are important predictors of job satisfaction, consistent with Hackman and Oldham's (1975, 1976) job design model. In contrast, measurement problems preclude accurate assessment of the predictive power of dispositional factors. Contrary to the concern raised by Staw and Ross (1985) and Staw, Bell, and Clausen (1986), it does not appear likely that the success of personnel programs will be significantly constrained by the influence of attitudinal consistency.
\end{abstract}

Locke (1969) defined job satisfaction as "a function of the perceived relationship between what one wants from one's job and what one perceives it as offering". Presumably, this definition points to the importance of both dispositional and situational factors as determinants of job satisfaction. In practice, however, Mitchell (1979) suggested that personality variables have received relatively little attention in empirical research on determinants of job attitudes. Similarly, Weiss and Adler (1984) argued that "researchers have barely scratched the surface on the ways in which personality constructs may enter into theoretical systems" (p. 43). There is disagreement, however, concerning the need for future research on personality or dispositional variables as determinants of job attitudes. In Mitchell's view, the "secondary role" played by dispositional variables "seems justified and necessary" (p. 247). In contrast, Weiss and Adler argued that "It is simply premature and unproductive to make any normative statements about restricting the role of personality in organizational research" (p. 2).

The role of dispositional factors or traits ${ }^{1}$ as determinants of job satisfaction has been examined in three recent empirical studies. Pulakos and Schmitt (1983) reported that high school students' instrumentalities for job-related outcomes measured prior to taking a job were predictive of subsequent job satisfaction. In their view, this finding suggests that "personnel selec-

I am grateful to John Boudreau, Peter Dowling, Lee Dyer, George Milkovich, and Sara Rynes for helpful comments on an earlier draft of this article.

Correspondence concerning this article should be addressed to Barry Gerhart, New York State School of Industrial and Labor Relations, Cornell University, Ithaca, New York 14851-0952. tion might benefit from more attention to selecting individuals who have a higher probability of being satisfied" (p. 311). An alternative interpretation, however, is that people who expected to receive relatively good jobs (i.e., had higher instrumentalities for valued outcomes) were, in fact, more likely to receive good jobs. These persons tended to be more satisfied because they received better jobs, not because of any propensity to be satisfied. To examine the impact of traits on job satisfaction, actual job outcomes must be controlled.

Staw and his colleagues conducted two studies designed to assess the impact of traits on job satisfaction. Staw, Bell, and Clausen (1986) found that adolescent "affective disposition" was correlated with adult job affect. Although Staw et al. interpreted this relation as evidence for the impact of traits on job satisfaction, the magnitude of the correlations was moderate, the sample sizes small, and control for job attributes limited, perhaps indicating a need to view these findings as suggestive only.

In contrast to the Staw et al. (1986) study, Staw and Ross (1985) sought to investigate both traits and job factors as determinants of job satisfaction, consistent with Locke's definition. They examined the temporal stability of a single, global jobsatisfaction item as a function of pay change, occupational status change, and previous global job satisfaction (measured 5 years earlier). Data were from the mature men cohort of the National Longitudinal Surveys of Labor Market Experience (NLS). Staw and Ross found that "satisfaction in 1966 was the strongest and most significant predictor of 1971 job attitudes.

\footnotetext{
${ }^{1}$ The term trait is used as a synonym for dispositional factors in this article.
} 
Neither changes in pay nor changes in job status accounted for nearly as much variance as prior job attitude" (p. 475).

Staw and Ross (1985) drew important implications from their study. They argued that "it is difficult to conclude from the present data that situational effects will supersede attitudinal consistency in most contexts" (p. 477). (Note that Staw and Ross attributed the predictive power of previous job satisfaction entirely to trait stability-the accuracy of this assumption is discussed later.) Regarding practical implications, they concluded that "many situational changes such as job redesign and organizational development may not affect individuals as they are intended" (p. 478; see Staw et al., 1986, for a similar argument).

These conclusions contrast sharply with the way many researchers view the relative importance of situational and trait factors as determinants of job satisfaction (cf. Mitchell, 1979). At an applied level, the Staw and Ross (1985) conclusions, if valid, suggest the need for a major reexamination of the value of personnel programs designed to affect worker attitudes and consequent behaviors through changes in the work environment. If Staw and Ross are correct, many such programs may be doomed to failure because worker attitudes are, to an important degree, a function of stable individual traits, not situational characteristics.

Several aspects of the Staw and Ross (1985) study, however, limit the validity of their conclusions. For example, Staw and Ross used a sample of men between the ages of 45 and 59 in 1966 and between the ages of 50 and 64 in 1971. Relative to younger workers, this older cohort is less likely to experience significant change in the work situation. In fact, using the same data set as Staw and Ross, the present author found a test-retest correlation of .84 for both pay and occupational status between 1966 and 1971. Given this high stability of situational factors, the test-retest correlation of .29 found by Staw and Ross for job satisfaction measured in 1966 and 1971 does not provide very convincing evidence of trait stability across time.

Moreover, given the high positive correlation $(r=.84)$ between the component parts of both pay and occupational status in their sample, the change scores used for pay and status by Staw and Ross (1985) in their satisfaction equations may have been very unreliable. Using a formula given by Guilford (1954, p. 394), the reliability of the difference scores used by Staw and Ross can be estimated under different assumptions. If in the cross section, the reliabilities of the pay and status measures had been .95 , the reliability of the difference scores would have been 69. However, .95 is probably an optimistic estimate (Jencks, 1979 , pp. 328-329). The true parameter may be considerably lower (Duncan \& Hill, 1985). Given the latter research, a crosssectional reliability of .85 to .90 may be more plausible, resulting in reliabilities for the Staw and Ross difference scores ranging from .06 to .38 .

Therefore, even if the measures of the pay and status components were reliable, the pay and status change scores used by Staw and Ross were probably very unreliable, thus resulting in a serious underestimation of the effects of these situational factors on job satisfaction. Under such circumstances, comparing the relative effects of situational factors and traits is not quite "fair" (Cooper \& Richardson, 1986).

One purpose of this article is to examine the relation of job satisfaction with both dispositional and situational factors in a sample of young adults who, in general, are likely to experience more significant changes in central aspects of their work situations. The greater sample variance in such changes provides a more sensitive test for situational effects. To facilitate comparison with the Staw and Ross results, similar methods are used to some extent, although it should be understood that this similarity does not indicate acceptance of the Staw and Ross methodology (e.g., interpretation of the coefficient on previous job satisfaction as indicative of the importance of stable traits).

Staw and Ross (1985) explicitly mentioned job redesign as an example of a personnel program that may not have the intended effects given their findings. Yet, no measure of job design was included in their study. Thus, a second purpose of the present study is to examine the relation between job complexity (Hackman \& Oldham, 1975, 1976, 1980) and job satisfaction. A recent meta-analysis (Loher, Noe, Moeller, \& Fitzgerald, 1985) found that only the study by Orpen $(1979 ; n=36)$ examined the impact of actual changes in job complexity in a field setting. More typically, research in this area has been cross-sectional and has focused on the relation between incumbent self-reports of job complexity and job satisfaction.

However, problems have been raised with the latter research design. First, common methods variance (Schwab \& Cummings, 1976; Roberts \& Glick, 1981) or priming and consistency effects (Salancik \& Pfeffer, 1978) may contribute to the observed relation between self-reports of job complexity and job satisfaction. (See Stone \& Gueutal, 1984, however, for evidence contrary to the latter.) Second, job design theory specifies that changes in job complexity will result in changes in job satisfaction. Thus, cross-sectional data have an inherent limitation with respect to testing this theory.

Given these concerns, the present study uses longitudinal data to assess the impact of changes in job complexity on job satisfaction. Moreover, in addition to a self-report measure, an independent complexity measure is derived from the 4th edition of the Dictionary of Occupational Titles (DOT; U.S. Department of Labor, 1977). Any relation between the latter measure of complexity and job satisfaction is not likely to be a function of the artifacts discussed by Schwab and Cummings (1976) or by Salancik and Pfeffer (1978). As in the Staw and Ross (1985) research, pay, occupational status, and previous job satisfaction are also examined as possible determinants of current job satisfaction.

\section{Method}

\section{Sample}

The data are taken from the youth cohort of the NLS, a national probability sample of 12,686 men and women between the ages of 14 and 21 in 1979 (and ages 17-24 in 1982). This sample was interviewed for the first time in 1979, with follow-up interviews conducted annually. The present study uses data from 1979 and 1982. If in either year a person was enrolled in school, was less than 17 years of age, had been working less than $20 \mathrm{hr}$ per week, or had been with the present employer less than 2 months, he or she was excluded from the sample. These restrictions were imposed to ensure the inclusion only of persons with strong labor force attachment. As a consequence, the sample size for the analyses to be reported here, unless noted otherwise, is 809 . These 
persons were distributed across more than 125 three-digit census occupations.

\section{Measures}

As in the Staw and Ross (1985) study, job satisfaction is measured using a single-item global satisfaction measure with four possible levels of response. The anchors range from dislike it [the job you have now] very much to like it very much. slightly different from the global jobsatisfaction item used in the Staw and Ross study, in which the anchors range from highly satisfied to highly dissatisfied. The construct validity of single-item measures is often questioned on at least two grounds: (a) lack of reliability and (b) lack of domain coverage. Nevertheless, in the case of job satisfaction, Scarpello and Campbell (1983) concluded that the single-item global satisfaction item in their study was not unreliable and was the "most inclusive measure of overall job satisfaction" (p. 598).

Also, as in the Staw and Ross (1985) study, employer change, occupational change, pay change, and status (Duncan's measure of socioeconomic status; Reiss, 1961) change are included as situational variables.

Some evidence suggests that instruments such as the Job Diagnostic Survey and the Job Characteristics Inventory (JCI) measure a unidjmensional construct (Aldag, Barr, \& Brief, 1981; Drasgow \& Miller, 1982). Furthermore, the appropriate label for this construct may be complexity (Gerhart, 1985; Hackman \& Oldham, 1980; Stone \& Gueutal, 1985).

Thus, the first measure of job complexity is essentially a short form of the JCI (developed by Sims, Szilagyi, \& Keller, 1976). Each of the six subscales of the JCI (Variety, Dealing With Others, Autonomy, Feedback, Task Identity, and Friendship Opportunities) is represented by one item that previous research has shown to load strongly on that dimension (see Sims et al., 1976). In addition, an item designed to measure task significance is included. Confirmatory factor analyses supported the use of a single-factor solution. Thus, the seven items were equally weighted and summed to form a scale hereafter referred to as incumbent perceptions of job complexity (IPJC). The internal consistency of this scale as estimated by the Spearman-Brown formula was .72 in 1979 , and .79 in 1982 . Further psychometric information on this scale can be found in Gerhart (1985).

A second measure of complexity used in the present study was derived by Roos and Treiman (1980) from the 4th edition of the Dictionary of Occupational Titles (U.S. Department of Labor, 1977) and is referred to as DOT-complexity in the present study. Sample items include complexity of function in relation to data, required intelligence, and required temperament for repetitive or continuous processes. Psychometric information on the DOT-complexity measure can be found in Cain and Treiman (1981), Cain and Green (1983), and Gerhart (1985).

Cain and Treiman (1981, p. 254) noted that the DOT has the advantage of being based not on worker self-reports but rather "on extensive on-site observation of jobs as they are actually performed and index job content rather than worker characteristics." It should be understood, however, that this measure represents average levels of complexity for entire occupations rather than jobs. ${ }^{2}$ To the extent that jobs in an occupation differ substantially from one another, error is introduced into the analysis. As a result, the true relation between job complexity and other variables will be underestimated using the DOT-complexity measure.

The DOT-based measure is useful, however, because of the way it complements the IPJC measure. First, in job analysis terms (McCormick, 1976), the DOT-based measure is dominated by items pertaining to personnel requirements, whereas the IPJC measure emphasizes work-oriented activities. Second, the source of information differs (i.e., incumbent vs. nonincumbent). As described earlier, these differences help control the effects of measurement artifacts such as common methods variance.
Table 1

Estimated Reliabilities of Measures

\begin{tabular}{lccc}
\hline \multicolumn{1}{c}{ Measure } & $\begin{array}{c}\text { Reliability } \\
\text { of component } \\
\text { parts }\end{array}$ & $\begin{array}{c}\text { Correlation } \\
\text { between } \\
\text { component } \\
\text { parts }\end{array}$ & $\begin{array}{c}\text { Reliability } \\
\text { of change } \\
\text { scores }^{2}\end{array}$ \\
\hline Job satisfaction & .80 & & \\
Previous job satisfaction & .80 & & \\
Previous pay & .90 & & \\
Current pay & .90 & & \\
Previous occupational status & .90 & & \\
Current occupational status & .90 & & \\
Previous DOT-complexity & .70 & & \\
Current DOT-complexity & .70 & & \\
Previous IPJC & .72 & & \\
Current IPJC & .79 & .53 & .79 \\
$\Delta$ Pay & & .58 & .76 \\
$\Delta$ Duncan & & .43 & .47 \\
$\Delta$ DOT-complexity & & .30 & .65 \\
\hline IPJC & & & \\
\hline
\end{tabular}

Note. DOT = Dictionary of Occupational Titles; IPJC = incumbent perceptions of job complexity.

'Based on the following formula (Guilford, 1954, p. 394):

$$
r_{d d}=\frac{r_{j j}+r_{k k}-2 r_{j k}}{2\left(1-r_{j k}\right)},
$$

where $r_{d d}=$ reliability of the difference $X_{i}-X_{k}, r_{j j}, r_{k k}=$ respective reliabilities of $X_{j}$ and $X_{k}$, and $r_{j k}=$ intercorrelation of $X_{j}$ and $X_{k}$. For example, in the case of DOT-complexity, $r_{j j}=r_{k k}=.70$, and $r_{j k}=.43$; thus,

$$
r_{d d}=\frac{.70+.70-2(.43)}{2(1-.43)}=.47 \text {. }
$$

\section{Analyses}

Because measurement error in either the independent or dependent variables biases estimates of standardized regression coefficients (Kenny, 1979), LISREL (Jöreskog \& Sörbom, 1981) was used to correct for the effects of measurement error. Given that change scores can exacerbate measurement error problems, this correction is especially important in the present context. In LISREL, correction for measurement error is made by fixing the error variance, theta delta, to $\left(1-r_{x x}\right) \sigma_{x}^{2}$ and by fixing the factor loading, lambda, equal to the square root of the reliability.

The reliability of pay and occupational status measures in surveys like the NLS is approximately .90 (Jencks, 1979). Based on previous research (i.e., Cain \& Green, 1983; Kohn \& Schooler, 1973; Spenner, 1980), Gerhart (1985) estimated the reliability of the DOT-complexity measure to be approximately .70 . This estimate includes both of the following sources of error: (a) interrater differences and (b) the use of an occupation level measure as a proxy for a job level construct. Guilford's (1954, p. 394) formula was used to estimate the reliabilities of the change scores used. Table 1 summarizes the reliability estimates used to correct for measurement error.

\footnotetext{
2 "Jobs are specific positions within establishments or the economic activities of specific individuals. They entail particular duties and responsibilities and involve the performance of particular tasks in particular settings. . . . Occupations are aggregations of jobs, grouped on the basis of their similarity in content" (Cain \& Treiman, 1981, p. 254).
} 
Table 2

Test-Retest Correlations for Global Job Satisfaction as a Function of Employer Change and Three-Digit Census Occupation Change

\begin{tabular}{crrrrr} 
& \multicolumn{2}{c}{ Same employer } & & \multicolumn{2}{c}{$\begin{array}{c}\text { Changed } \\
\text { employer }\end{array}$} \\
\cline { 2 - 3 } \cline { 5 - 6 } Occupation & $1^{2}$ & $2^{\mathrm{b}}$ & & $1^{\mathrm{a}}$ & $2^{\mathrm{b}}$ \\
\hline $\begin{array}{c}\text { Same } \\
r\end{array}$ & .36 & .37 & & .30 & .23 \\
$n$ & 139 & 1,711 & & 90 & 1,232 \\
$\begin{array}{c}\text { Changed } \\
r\end{array}$ & .22 & .24 & & .19 & .19 \\
$n$ & 234 & 274 & 569 & 1,121 \\
\hline
\end{tabular}

a Present study (1979 and 1982 data). ${ }^{b}$ Corresponding correlations and sample sizes from the Staw and Ross (1985) study.

In addition to correcting for unreliability in the situational variables, job satisfaction was also regressed on the 1979 and 1982 measurements of pay and status, rather than on changes in these variables, because the use of change scores implicitly assumes an arbitrary weighting scheme (i.e., weights of +1 and -1 , respectively, for the two component parts of the change score) that may fail to maximize the explanatory power of the regression equation (Cronbach \& Furby, 1970; Glansnapp, 1984).

\section{Results}

The correlation between 1979 and 1982 satisfaction is .22 , somewhat lower than the correlation found by Staw and Ross (1985) between two satisfaction measurements 3 years apart $(r=.32)$. Table 2 shows the correlations between satisfaction in 1979 and 1982 as a function of employer and three-digit census occupational change. Table 2 also contains the corresponding results from the Staw and Ross study (using the correlations between 1966 and 1971 satisfaction in their Table 2). The correlations in the two studies are similar despite the fact that the age groups and time intervals differ. In both studies, however, significant differences in consistency exist as a function of the rough proxies for situational change (i.e., change in occupation or employer). These differences are more obvious if one squares the correlations to obtain estimates of variance explained. Both studies, for example, indicate that when neither occupation nor employer changed, the explained variance is $13 \%-14 \%$. However, when occupation and employer both change, variance explained declines to $4 \%$.

These differences seem to demonstrate that situational changes do, in fact, make a difference even when crudely measured. In addition, however, the similarities across the two studies suggest another important point-the age differences between the samples do not appear to be important within these rough classifications. The key, however, is that the proportions within these cells differ strongly between the studies, with a far greater percentage of persons changing occupations and employers in the present sample. This difference explains the smaller overall test-retest correlation found in this study. It also explains the lower test-retest correlations found for pay and status (.53 and .54 , respectively, versus .84 for both measures in the Staw and Ross, 1985, study).
Recall that Staw and Ross found little change in $R^{2}\left(\Delta R^{2}=\right.$ .004 ) associated with adding changes in pay and status to their equation for job satisfaction. In contrast, the reestimations of the Staw and Ross models using the NLS youth cohort data indicate that changes in pay and status do seem to make a difference in employee job satisfaction (see Table 3). This conclusion is further strengthened by reestimation of the model using (a) the component parts and (b) the corrections for measurement error.

To directly test the effects of changes in job complexity on job satisfaction, models incorporating the two measures of complexity were estimated. These results appear in Table 4. In this case, support for the importance of situational changes is even stronger. Significant increments in $R^{2}$ are achieved by adding the situational variables to the equation. When using the separate 1979 and 1982 component scores, the coefficients on the complexity variables approach (DOT-complexity) or exceed (IPJC) the magnitude of the coefficient on previous job satisfaction.

As before, the model was reestimated using the corrected change and component scores. Once again, stronger support for the importance of situational changes was obtained when procedures were used to correct for measurement error. In Table 4, Equation 3b, the coefficient on current DOT-complexity exceeds that for previous job satisfaction. In Equation $5 b$, the coefficient on current IPJC is more than double that of the coefficient on previous job satisfaction. These results suggest that job complexity may be an important determinant of job satisfaction.

A final issue concerns the possible impact of unreliability in the single-item job-satisfaction measures. Because there is only one item, an internal consistency reliability estimate could not be computed. Nevertheless, it may be that correcting measurement error only in the situational variables stacks the deck in favor of finding significant situational effects. This issue can be

Table 3

Job Satisfaction as a Function of Previous Job Satisfaction, Pay, and Occupational Status

\begin{tabular}{|c|c|c|c|c|c|}
\hline \multirow[b]{2}{*}{ Variable } & \multicolumn{3}{|c|}{ Uncorrected $^{a}$} & \multicolumn{2}{|c|}{ Corrected $^{b}$} \\
\hline & la & $2 \mathbf{a}$ & $3 a$ & $2 b$ & $3 b$ \\
\hline $\begin{array}{l}\text { Previous job } \\
\text { satisfaction }\end{array}$ & $.26^{* *}$ & $.26^{* *}$ & $.26^{* *}$ & $.27^{* *}$ & $.26^{* *}$ \\
\hline Previous pay & & & $-.09^{*}$ & & $-.11^{* *}$ \\
\hline Current pay & & & $.07^{*}$ & & $.09 *$ \\
\hline $\begin{array}{l}\text { Previous occupational } \\
\text { status }\end{array}$ & & & -.05 & & -.07 \\
\hline $\begin{array}{l}\text { Current occupational } \\
\text { status }\end{array}$ & & & $.15^{* *}$ & & $.17^{* *}$ \\
\hline $\begin{array}{l}\Delta \text { Pay } \\
\Delta \text { Status }\end{array}$ & & $\begin{array}{l}.06^{*} \\
.09^{* *}\end{array}$ & & $\begin{array}{l}.07^{*} \\
.11^{* *}\end{array}$ & \\
\hline$R^{2}$ & .066 & .078 & .087 & .082 & .092 \\
\hline
\end{tabular}

Note. Different equation numbers $(1,2,3)$ indicate inclusion of different sets of predictors. Different equation letters $(a, b)$ indicate different assumptions about measure reliabilities. Entries in columns are standardized partial regression coefficients.

- Not corrected for measurement error. ${ }^{b}$ Corrected for measurement error in situational variables only.

$* p<.05$, one-tailed. ${ }^{* *} p<.01$, one-tailed. 
Table 4

Job Satisfaction as a Function of Previous Job Satisfaction, Pay, IPJC, and DOT-Complexity

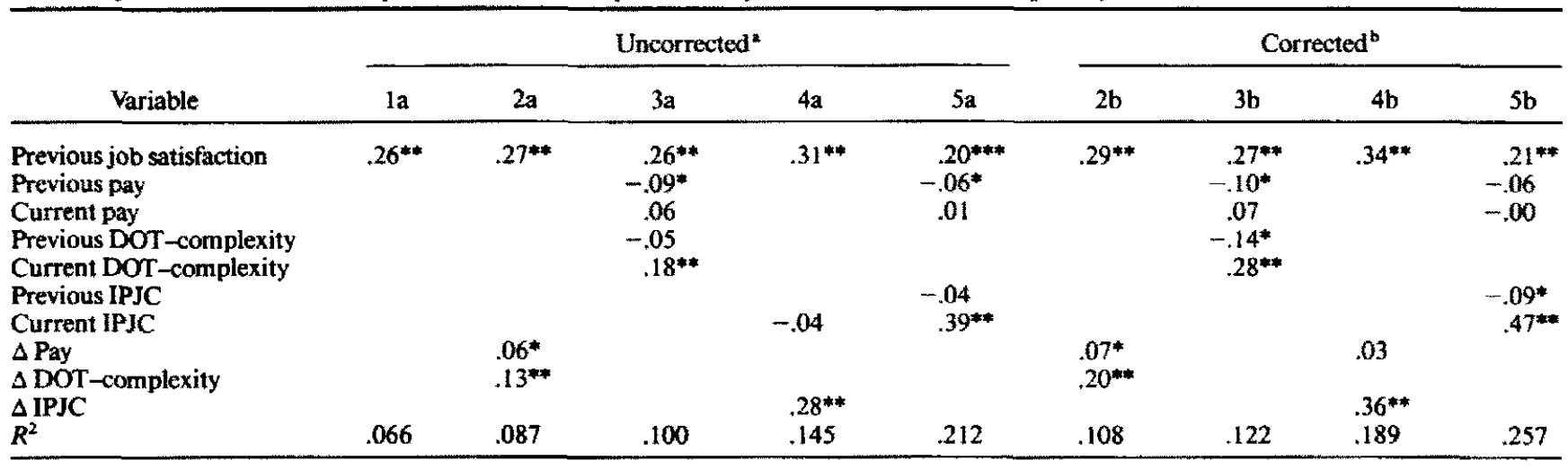

Note. Different equation numbers $(1,2,3,4,5)$ indicate inclusion of different sets of predictors. Different equation letters (a,b) indicate different assumptions about measure reliabilities. Entries in columns are standardized partial regression coefficients. IPJC $=$ incumbent perceptions of job complexity; DOT = Dictionary of Occupational Titles.

- Not corrected for measurement error. ${ }^{b}$ Corrected for measurement error in situational variables only.

$* p<.05$, one-tailed. ${ }^{* *} p<.01$, one-tailed.

addressed in two ways. First, note that both Tables 3 and 4 indicate that even without correction for measurement error, the situational factors have a significant effect on job satisfaction. Nevertheless, a second strategy was to reestimate the corrected models using arbitrary reliability estimates of .80 and .60 for both satisfaction measures to determine if the findings would be altered. As Tables 5 and 6 demonstrate, the relative importance of the situational factors is largely unaffected by this unreliability correction.

\section{Discussion}

One purpose of this study was to assess recent suggestions that traits may be more important determinants of job satisfaction than previously believed and that personnel programs designed to change the work environment may be rendered ineffective in many cases because of the impact of these stable traits. Results of the present study, however, indicate that pay, status, and job complexity added explanatory power to an equation predicting job satisfaction, controlling for earlier job satisfaction. The job complexity measures, in particular, were strong predictors.

These findings differ strongly from the Staw and Ross (1985) study that found little predictive power for situational factors. Perhaps the most straightforward explanation for these conflicting findings is that the present study used a sample that experienced more significant variance in changes in job attributes over time. This sample characteristic seems desirable because personnel programs such as job design entail changes in job attributes. In addition, the present research directly examined changes in job complexity, the core construct of Hackman and Oldham's $(1975,1976)$ job design model. The focus on estimating relations corrected for measurement error also contributed to stronger estimated situational effects.

Table 5

Robustness of Results to Varying Assumed Levels of Job Satisfaction Reliability: Occupational Status

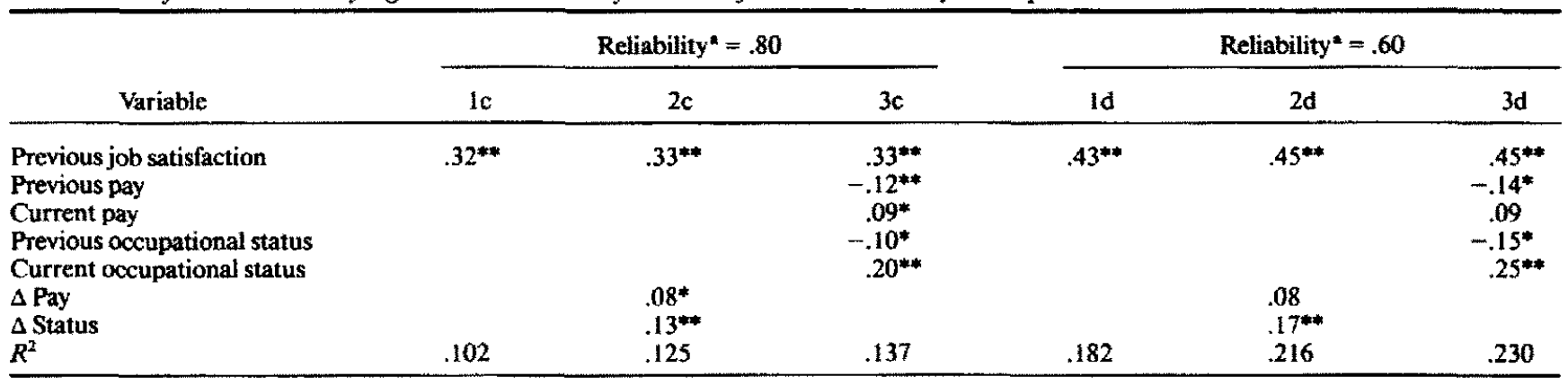

Note. Situational variables are corrected for measurement error. Column entries are standardized partial regression coefficients. Different equation numbers $(1,2,3)$ indicate inclusion of different sets of predictors. Different equation letters $(c, d)$ indicate different assumptions about measure reliabilities.

Assumed reliability of previous and current job satisfaction.

$* p<.05$, one-tailed. $* * p<.01$, one-tailed. 
Table 6

Robustness of Results to Varying Assumed Levels of Job Satisfaction Reliability: Job Complexity

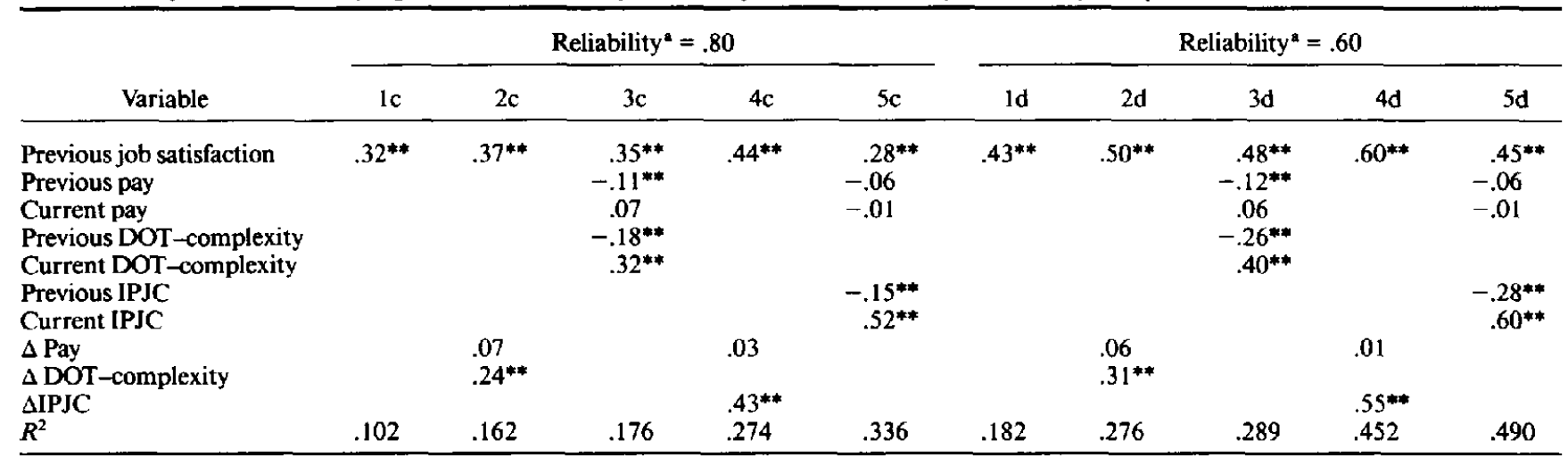

Note. Situational variables are corrected for measurement error. Column entries are standardized partial regression coefficients. Different equation numbers $(1,2,3,4,5)$ indicate inclusion of different sets of predictors. Different equation letters $(c, d)$ indicate different assumptions about measure reliabilities. DOT = Dictionary of Occupational Titles; IPJC = incumbent perceptions of job complexity.

- Assumed reliability of previous and current job satisfaction.

$* p<.05$, one-tailed. ${ }^{* *} p<.01$, one-tailed.

These findings are potentially important for the job design area because of several methodological strengths. First, longitudinal data were used. Thus, the effect of changes in levels of complexity on job satisfaction could be examined. Second, the research was conducted in a field setting and included a wide range of occupations. Therefore, the lack of external validity sometimes attributed to laboratory research using students may have been less of a problem (see Stone, 1986, however, for evidence supporting the external validity of laboratory research in the job design area). Third, both measures of complexity were related to job satisfaction. Given that the two measurement methods for complexity were quite different, it is unlikely that the observed complexity-satisfaction relation can be explained in terms of measurement artifacts such as priming and consistency effects or common methods variance.

Despite these advantages, note that the changes experienced by workers in this sample may be qualitatively different from the changes experienced as the result of an intervention in a single organization. Moreover, there may be unmeasured changes in other situational factors confounded with changes in complexity that also influence satisfaction. If true, the coefficients on the complexity variables would be biased. To examine this possibility, several additional situational factors ${ }^{3}$ were added to Table 4, Equations 3a and 5a. The addition of these variables, however, changed the coefficients on current IPJC and current DOT-complexity by less than $10 \%$, suggesting that the estimated effects of complexity may, in fact, be quite robust.

Similar to Staw and Ross's (1985) findings, I found that previous job satisfaction predicted current job satisfaction. One interpretation of this predictive power is to follow the reasoning of Staw and Ross and attribute it to the importance of traits that remain stable over time and across situations.

There are two problems with this explanation, however. First, to the extent that important situational variables are omitted or poorly measured, the relative predictive power of previous job satisfaction will appear greater. Second, and closely related, no specific individual variables were specified by Staw and Ross as accounting for the (moderate) stability in job satisfaction. Instead, any unexplained stability in job satisfaction was attributed to unspecified traits. The theoretical rationale for such an attribution is not at all clear, as was later acknowledged by Staw et al. (1986): "Such consistency data do not, however, constitute a dispositional theory of attitudes, since they have little to say about why individuals may show stability in job satisfaction" (p. 60). As a consequence, Staw et al. attempted to better define a specific trait (i.e., affective disposition).

It may be more accurate to interpret the predictive power of previous job satisfaction in the Staw and Ross (1985) study as indicative of some degree of stability in both traits and job attributes given that previous job satisfaction is itself a function of both types of factors (Locke, 1969). Thus, an observed relation between previous and current job satisfaction should perhaps be viewed as an upper bound on the total effect of traits on job satisfaction.

Finally, from an applied view, an impact of traits on global job satisfaction may have little relevance for at least two reasons. First, organizations often focus their efforts on improving specific aspects of the work situation with which employees are dissatisfied. Specific facet satisfaction measures may better reflect changes in relevant situational factors because of the more precise referent. Although the NLS has sparse information on facet satisfaction, it did ask respondents how true the following statement was of their job: The pay is good. The $R^{2}$ obtained by predicting this rough measure of pay satisfaction in 1982 with the corresponding 1979 measure was .07 . Adding pay change

\footnotetext{
${ }^{3}$ The 1979 and 1982 measures for the following variables were added to the equations: (a) working conditions, (b) physical demands, (c) required motor skills, (d) firm tenure, (e) weekly hours worked, (f) presence or absence of health insurance, (g) presence or absence of a paid vacation benefit, (h) presence or absence of life insurance, and (i) Duncan's measure of occupational status (the same as that included in Table 3). Inclusion of Duncan's measure of occupational status helps control for any influence of occupational progression among young adults.
} 
to the equation, however, increased the $R^{2}$ to .20 (without any correction for measurement error). This finding provides tentative support for the proposition that specific facet (vs. global) satisfaction measures may be more responsive to changes in situational factors.

Second, one may simply not care if satisfaction is correlated over time due to stable traits. More relevant in many cases will be the question of whether the average level of job satisfaction of workers can be increased through the use of some program. If, as the present results suggest, the level does increase in response to certain situational changes, the question of whether workers maintain their relative positions over time (as assessed by correlational methods) may not be important. ${ }^{4}$

In conclusion, the present research does not support Staw and Ross's (1985) conclusion that attitudinal consistency will equal or exceed the effects of situational factors in most contexts. Support for the importance of situational factors such as job complexity was found. In contrast, direct evidence for the importance of traits as determinants of job satisfaction was not obtained in either study. An adequate test for the impact of traits requires the specification and testing of models containing specific trait measures.

\section{Implications}

I suggest the following important practical implications. First, there is little evidence that "Many situational interventions may be prone to failure because they must contend with attitudinal consistency" (Staw \& Ross, 1985, p. 478; see also Staw et.al., 1986). The present results demonstrate that changes in situational factors such as job complexity and pay may have an important impact even on global job satisfaction. This impact may be greater for specific facets of satisfaction that personnel programs often target.

Second, even if there is stability in the relative satisfaction of workers over time, the overall level of satisfaction may still be increased by well-designed personnel programs. Therefore, the practical significance of attitudinal consistency may be minimal unless such consistency is shown to place an important constraint on changes in job-satisfaction levels.

Finally, until more compelling evidence for the impact of stable traits on job satisfaction is found, personnel selection based on traits (e.g., propensity to be satisfied) may be premature. It is important to remember that even conceptually stable traits such as intellectual flexibility have been found to change in response to situational factors like job complexity (Kohn \& Schooler, 1973, 1982). To the extent that traits lack stability, their predictive validity is diminished. The longstanding conclusion that personality traits have suspect predictive validity (Guion \& Gottier, 1965) may still apply.

\footnotetext{
4 Statistical methods requiring longitudinal data (e.g., first-differencing models) are available that yield unbiased estimates of changing situational factors even in the presence of unmeasured, but stable, trait factors (e.g., Gerhart, 1985; Mundlak, 1978).

\section{References}

Aldag, R. J., Barr, S. H., \& Brief, A. P. (1981). Measurement of perceived task characteristics. Psychological Bulletin, 90, 415-431.
}

Cain, P. S., \& Green, B. F. (1983). Reliabilities of selected ratings available from the Dictionary of Occupational Titles. Journal of Applied Psychology. 68, 155-165.

Cain, P. S., \& Treiman, D. J. (1981). The Dictionary of Occupational Titles as a source of occupational data. American Sociological Review, 46, 253-278.

Cronbach, L. J., \& Furby, L. (1970). How we should measure "change"-or should we? Psychological Bulletin, 74, 68-80.

Cooper, W. H., \& Richardson, A. J. (1986). Unfair comparisons. Journal of Applied Psychology, 71, 179-184.

Drasgow, F. P., \& Miller, H. E. (1982). Psychometric and substantive issues in scale construction and validation. Journal of Applied Psychology, 67, 268-279.

Duncan, G. J., \& Hill, D. H. (1985). An investigation of the extent and consequences of measurement and error in labor-economic survey data. Journal of Labor Economics, 3, 508-532.

Gerhart, B. (1985). Sources of variance in perceptions of job complexity. Unpublished doctoral dissertation, University of Wisconsin-Madison.

Glansnapp, D. R. (1984). Change scores and regression suppressor conditions. Educational and Psychological Measurement, 44, 851-867.

Guilford, J. P. (1954). Psychometric methods (2nd ed.). New York: McGraw-Hill.

Guion, R. M., \& Gottier, R. F. (1965). Validity of personality measures in personnel selection. Personnel Psychology, 31, 841-852.

Hackman, J. R., \& Oldham, G. R. (1975). Development of the Job Diagnostic Survey. Journal of Applied Psychology. 60, 159-170.

Hackman, J. R., \& Oldham, G. R. (1976). Motivation through the design of work: Test of a theory. Organizational Behavior and Human Performance, I6, 250-279.

Hackman, J. R., \& Oldham, G. R. (1980). Work redesign. Reading, MA: Addison-Wesley.

Jencks, C. J. (1979). Who gets ahead? New York: Basic Books.

Jöreskog, K. G., \& Sörbom, D. (1981). LISREL V. Uppsala, Sweden: University of Uppsala.

Kenny, D. A. (1979). Correlation and causality. New York: Wiley.

Kohn, M. L., \& Schooler, C. (1973). Occupational experience and psychological functioning: An assessment of reciprocal effects. American Sociological Review, 38, 197-118.

Kohn, M. L., \& Schooler, C. (1982). Job conditions and personality: A longitudinal assessment of their reciprocal effects. American Journal of Sociology, 87, 1257-1286.

Locke, E. A. (1969). What is job satisfaction? Organizational Behavior and Human Performance, 4, 309-336.

Loher, B. T., Noe, R. A., Moeller, N. L., \& Fitzgerald, M. P. (1985). A meta-analysis of the relation of job characteristics to job satisfaction. Journal of Applied Psychology, 70, 280-289.

McCormick, E. J. (1976). Job and task analysis. In M. D. Dunnette (Ed.), Handbook of industrial and organizational psychology (pp. 651-696). Chicago: Rand-McNally.

Mitchell, T. R. (1979). Organizational behavior. In M. R. Rosenweig \& L. W. Porter (Eds.), Annual review of psychology (Vol. 30, pp. 243 281). Palo Alto, CA: Annual Reviews.

Mundlak, Y. (1978). On the pooling of time series and cross-sectional data. Econometrica, 46, 69-85.

Orpen, C. (1979). The effects of job enrichment on employee satisfaction, motivation, involvement, and performance: $A$ field experiment. Human Relations, 32, 189-217.

Pulakos, E. D., \& Schmitt, N. (1983). A longitudinal study of a valence model approach for the prediction of job satisfaction. Journal of $A p$ plied Psychology, 68, 307-312.

Reiss, A. (1961). Occupations and social status. New York: Free Press.

Roberts, J., \& Glick, W. (1981). The job characteristics approach to task design: A critical review. Journal of Applied Psychology, 66, 193217. 
Roos, P. A., \& Treiman, D. J. (1980). Worker functions and worker traits for the 1970 U.S. census classification. In A. R. Miller, D. J. Treiman, P. S. Cain, \& P. A. Roos (Eds.), Work, jobs, and occupations: A critical review of the Dictionary of Occupational Titles (Appendix F). Washington, DC: National Academy Press.

Salancik, G. R., \& Pfeffer, J. (1978). A social information processing approach to job attitudes and task design. Administrative Science Quarterly, 23, 224-253.

Scarpello, V., \& Campbell, J. P. (1983). Job satisfaction: A re all the parts there? Personnel Psychology, 36, 577-600.

Schwab, D. P., \& Cummings, L. L. (1976). Impact of task scope on employee productivity: An evaluation using expectancy theory. Academy of Management Review, 1, 23-35.

Sims, H., Szilagyi, A., \& Keller, R. (1976). The measurement of job characteristics. Academy of Management Journal, 19, 195-212.

Spenner, K. I. (1980). Occupational characteristics and classification systems: New use of the Dictionary of Occupational Titles in social research. Sociological Methods and Research, 9, 239-264.

Staw, B. M., Bell, N. E., \& Clausen, J. A. (1986). The dispositional approach to job attitudes: A lifetime longitudinal test. Administrative Science Quarterly, 31, 56-77.

Staw, B. M., \& Ross, J. (1985). Stability in the midst of change: A dispo- sitional approach to job attitudes. Journal of Applied Psychology, 70 , 469-480.

Stone, E. F. (1986). Job scope-job satisfaction and job scope-job performance relationships. In E. A. Locke (Ed.), Generalizing from laboratory to field settings: Research findings from industrial-organizational psychology, organizational behavior and human resource management (pp. 189-206). Lexington, MA: Lexington Books.

Stone, E. F., \& Gueutal, H. (1984). On the premature death of need satisfaction models: An investigation of Salancik and Pfeffer's views on priming and consistency artifacts. Journal of Management, 10, 237-258.

Stone, E. F., \& Gueutal, H. (1985). An empirical derivation of the dimensions along which characteristics of jobs are perceived. Academy of Management Journal, 28, 376-396.

U.S. Department of Labor. (1977). Dictionary of Occupational Titles (4th ed.). Washington, DC: U.S. Government Printing Office.

Weiss, H. M., \& Adler, J. (1984). Personality and organizational behavior. In B. M. Staw \& L. L. Cummings (Eds.), Research in organizational behavior (Vol. 6, pp. 1-50). Greenwich, CT: JAI Press.

Received March 28, 1986

Revision received February 2, 1987

Accepted January 8, 1987

\section{Correction to Earley et al.}

In the article "Task Planning and Energy Expended: Exploration of How Goals Influence Performance," by P. Christopher Earley, Pauline Wojnaroski, and William Prest (Journal of Applied Psychology, 1987, Vol. 72, No. 1, 107-114), Table 1 on page 109 appeared with reversed labels for the high and low conditions. The corrected Table 1 is as follows:

Table 1

Means, Standard Deviations, and Intercorrelations of

Performance, Planning, and Energy Expended for

Goal and Information in Study 1

\begin{tabular}{lccccc}
\hline & \multicolumn{5}{c}{ Goal } \\
\cline { 2 - 3 } \cline { 5 - 6 } $\begin{array}{l}\text { Measure and } \\
\text { information }\end{array}$ & \multicolumn{2}{c}{ "Do best" } & & \multicolumn{2}{c}{ Specific } \\
\cline { 2 - 3 } \cline { 5 - 6 } & $M$ & $S D$ & & $M$ & $S D$ \\
\hline $\begin{array}{l}\text { Performance } \\
\text { Low }\end{array}$ & 8.26 & 1.98 & & 20.25 & 6.72 \\
$\quad$ High & 15.32 & 2.26 & & 25.14 & 6.56 \\
Planning & & & & \\
$\quad$ Low & 1.78 & 0.49 & & 3.23 & 0.52 \\
$\quad$ High & 2.57 & 0.73 & & 3.39 & 0.85 \\
Energy expended & & & & \\
$\quad$ Low & 2.61 & 0.60 & & 3.24 & 0.63 \\
$\quad$ High & 3.35 & 0.53 & & 3.76 & 0.59 \\
\hline
\end{tabular}

a $n=18 /$ cell. ${ }^{b}$ Dummy-coded 0,1 . 